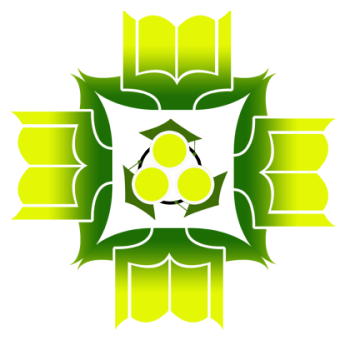

\title{
MALAY CULTURE-BASED CHARACTER EDUCATION MODEL FOR ELEMENTARY SCHOOL-AGED CHILDREN IN URBAN MALAY-MUSLIM FAMILY IN PONTIANAK
}

\author{
Syamsul Kurniawan \\ Institut Agama Islam Negeri (IAIN) Pontianak \\ syamsulkurniawan001@gmail.com \\ Muhammad Miftah \\ Institut Agama Islam Negeri (IAIN) Kudus \\ muhammadmiftah@stainkudus.ac.id
}

\begin{abstract}
This paper aims to describe Malay culture-based character education model in Muslim-Malay families in Pontianak. This qualitative research in the form of case study was conducted in 2019. The data was obtained through interview and direct observation. The qualitative analysis model followed the procedure suggested by Mathew B. Miles, et al. The results of this study indicate that the Muslim-Malay urban families in Pontianak have used Malay culture-based on character education model. This model is implemented through the values of virtue and exemplary from the Malay culture. This model is given through the intervention and habituation of characters from their Malay culture. The character building of urban MalayMuslim family in Pontianak had a number of challenges as the consequence of time change. Elementary school children familiarity with communication, media and digital technology have positive and negative impact, depending on their ability to sort out the information they read or download. It is same with the use of social media, such as Facebook, Instagram, WhatsApp, YouTube and other social media. In this context, parents need to guide their children.
\end{abstract}

Keywords: Character Education Model, Malay Culture, Elementary School; Muslim-Malay Urban Family. 


\begin{abstract}
Abstrak
Tujuan dari tulisan ini adalah mendeskripsikan model pendidikan karakter berbasis kultur melayu pada keluarga muslim-melayu urban di Pontianak. Tulisan ini berangkat dari sebuah riset kualitatif yang peneliti lakukan pada tahun 2019, yang mana data-data penelitian diperoleh dari interview dan observasi langsung, serta mengambil bentuk studi kasus. Adapun analisis yang digunakan adalah model analisis kualitatif yang mengikuti prosedur yang disarankan Mathew B. Miles, dkk. Hasil penelitian ini menunjukkan bahwa keluarga muslim-melayu urban di Pontianak telah menggunakan model pendidikan karakter yang berbasis kultur Melayu mereka. Model ini diberikan melalui penerapan nilai-nilai kebajikan dan keteladanan yang bersumber pada kultur melayu. Atau dengan kata lain, model ini diberikan melalui campur tangan dan habituasi karakter yang sumbernya dari kultur melayu mereka. Namun, kerja-kerja membangun karakter dalam keluarga muslim-melayu urban di Pontianak ini dihadapkan pada sejumlah tantangan yang menjadi konsekuensi dari perubahan zaman. Keakraban anak-anak usia SD sekarang dengan komunikasi, media, dan teknologi digital bisa berdampak positif atau negatif, amat bergantung dari kemampuan mereka memilah informasi yang mereka baca atau unduh. Demikian pula penggunaan media sosial, seperti facebook, instagram, whatsapp, youtube dan semacamnya. Pada konteks inilah, orang tua perlu mendampingi anak-anak mereka.
\end{abstract}

Kata Kunci: Kultur Melayu; Model Pendidikan Karakter; Siswa Sekolah Dasar; Keluarga Muslim-Melayu Urban

\title{
INTRODUCTION
}

Character education is education that instills and develops noble characters in children, so that they have these noble characters, apply and practice them in their lives, not only in the family but also as part of the community or citizens. This character education is a mandate from Law Number 20 of 2003 concerning the National Education System that must be implemented. In this law, in Chapter II, Article 3, it is stated that the purpose of national education is the development of capabilities and the formation of a dignified national character and civilization in the context of the intellectual life of the nation, the development of the potential of the nation's children so that they have faith and piety to God Almighty, have a noble character, are healthy, knowledgeable, capable, creative, independent, and later become a democratic and responsible citizen (Editor of Sinar Grafika, 2003 , p. 7). It aims to create students who are good in their faith, pious and form students to have good character values (Itsnaini et al, 2021, p. 14-23). 
Moreover, in this decade, many observers have indicated the importance of character education (Azzet, 2016, p. 15; Kurniawan, 2013, p. 19; Saptono, 2011, p. 25; Wibowo, 2012, p. 19-20; Yaumi, 2014, p. 44; Zubaedi, 2011, p. 41). Of course, it is not only because character education is a mandate of this law, but it is also because the current trend of character decline in Indonesia is so worrying (Bahri, 2015, p. 59; Budiarto, 2020, p. 51; Prihatmojo \& Badawi, 2020, p. 143).

How come? Referring to data from the Indonesian Child Protection Commission (KPAI), in the last three years, this declining character trend has targeted elementary school-aged children (SD). (jpnn.com, 2019; Kompas. com, 2020; okezone, 2018) This trend is understandable if it is referred to the arguments of HAR Tilaar, who sees it as a consequence of social change. (Tilaar, 2005, p. 3) Therefore, Muhammad Mustaqim assessed that character education should be given to children since they were elementary school age (Mustaqim, 2015 , p. 157,162). Of course, the implementation must be taken seriously with full commitment; not just for the sake of fulfilling obligations under the law (Miftah, 2017, p. 233).

However, there is a strong reason why children should not only accept the character education from their schools. The role of the family about this is much more important. The reason, as referring to Kamrani Buseri, is that upon returning from school, they will return home, and receive education from their parents and other adults in the family (Buseri, 2012, p. 11). So no matter how good the professionalism and work discipline of teachers in educating these children at school (Dewi \& Khotimah, 2020, p. 279-294; Yunus, 2016, p. 112-128), their character is still determined when they return from school; when they gather in the family (Arifin, 1976, p. 88-109).

In this connection, the character education model applied to a family determines the quality of the character education these children receive after school. Of course, the character education model between one family in a certain society and another, there can be different. This is because the culture from one society to another can be different too (Muchtar et.al, 2019, p. 117).

In urban Pontianak, the people who are generally Malay also have a kind of character education model that comes from their local wisdom. Even 
though the social conditions are urban, there are still quite a lot of people in this community who practice this model, especially those with a Muslim-Malay background. The educational model that is practiced in urban Malay-Muslim families in Pontianak for their elementary school-age children is still very traditional. Meanwhile, in general, urban communities, as Soerjono Soekamto argued, generally have untraditional characteristics, such as: first, religious life in urban areas is less than religious life in rural areas. Religious activities are usually limited to places of worship. Meanwhile, outside of that, people's lives are in the economic environment, trade. His lifestyle tends to be less religious than people with a rural typology. Second, they are characterized by being good at taking care of themselves, so the impression is very individualistic. Consequently, the social relations that take place between them are usually less intimate. In the public, social relations are usually united by common political, economic, and other interests. Third, the division of labor is also more assertive and has clear boundaries than people with a rural typology. Fourth, there are many alternative types of work that are involved when compared to rural areas which are generally homogeneous in this regard. The work types in the typology of urban society are wider because there are usually many kinds of industries. Fifth, the rational way of thinking that is generally adopted causes interactions between them to occur more based on pragmatic interests. Sixth, the fast pace of life in urban areas results in the perception of how valuable time is for pursuing pragmatic needs (Soekamto, 2009, p. 139).

Referring to M. Murtak's explanation, culture-based character education models generally highlight the importance of exemplary elements (Murtako, 2015, p. 149). Maintain a cultural heritage that can strengthen the character of love for the Indonesian homeland (Rahayuningtyas et al, 2021, p. 27-37). It is similar to the character education model that is practiced in urban Malay-Muslim families in Pontianak. In Pontianak, character education is given to elementary school-aged children, especially through exemplary and habituation of virtue values that are rooted in the Pontianak Malay culture. This aspect is the focus of this paper, namely 'a character education model based on Malay culture in urban Malay-Muslim families in Pontianak'. 


\section{METHODS}

This paper departs from qualitative research that the researcher conducted in 2019, in which the data was obtained from interviews and direct observations in Pontianak as the social setting. This research takes the form of a case study, which John W. Creswell says is a form of research that focuses on the specifics of a case in an event, whether it includes individuals, cultural groups, or a portrait of life (Creswell, 2009, p. 37-38). As the focus, the informants who become the source of research data are urban Malay-Muslim families in Pontianak, especially parents and their children of low-grade elementary school-aged. The subject of this research was taken by purposive sampling. The data that the authors collected from the interviews are added from the results of observations and documentation then it was reduced and conclusions are taken as analysis material. The analysis used is a qualitative analysis model, whose data is processed in-depth following the qualitative analysis procedures of Mathew B. Miles, et al (Miles et al., 2014, p. 21).

\section{RESULT AND DISCUSSION}

\section{Muslim-Malay Community in Urban Pontianak}

Administratively, Pontianak, which is home to the urban MalayMuslim families discussed, is the capital city of West Kalimantan Province. Administratively, Pontianak has 6 sub-districts and 29 urban villages, namely West Pontianak, Pontianak City, South Pontianak, Southeast Pontianak, East Pontianak, and North Pontianak (Bappeda Pontianak City, 2018). Here's the Map:

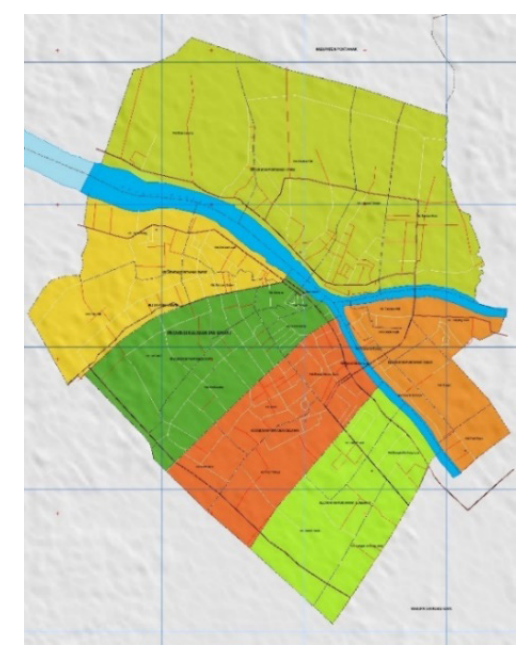

Figure 1. Pontianak City Map 
Comparing to the situation in Pontianak 20 years ago, the education that is received by the majority of the Malay-Muslim community in Pontianak currently is relatively better. Some children who finish elementary school will continue to higher education levels, junior high school, senior high school, and so on until college. Even so, some are uneducated, or who only finish their education at the elementary school level, but the number is not much. The reason is economic limitations and also 'customs'. In the past, in Pontianak, girls tended to be married off when they had completed primary or secondary education, so they did not continue their education.

Concerning the composition of ethnicity and religion, currently, urban Pontianak is very heterogeneous. In Pontianak, Malay-Muslims ordain themselves as indigenous tribes, while other tribes such as Bugis, Javanese, Madurese, Batak, Chinese, Dayak, and others are considered as immigrant tribes. But in the economy, the Malays are not dominant, but the Chinese. The Chinese tribe can be said to dominate almost all lines of economic sectors, such as workshops, trade, and others (Ode, 1997, p. 92).

In the kinship system, urban Malay-Muslims in Pontianak adhere to the bilateral or parental principle and adhere to the extended family. In this system, kinship is related in a balanced way, both on the father's and mother's path. In the eyes of their children, the father and mother play an equal role, although the head of the household remains on the father's shoulders. So even though they are equal, in certain cases, a father can still be dominant in making decisions on behalf of the family. Apart from that, in association, we recognize seniority based on age, namely from kinred (a group consisting of relatives) who are respected by other kinred because of the consideration of their older age (Soekamto, 2009, p. 56).

According to urban Malay-Muslim culture in Pontianak, children are dependent on their parents until they can support themselves and/or are married. In marriage, the social status of daughters which shifts from parents' to husband's responsibility is not very clear. The reason is that the system adopted is a matrilocal system that tends to do so. So, newly married families usually live together in the same house with the woman's family for a certain time, depending on the judgment of the woman's parents; whether this newly married couple can run their household independently, or remain in the same pot with their female parents. 
Urban Malay-Muslims in Pontianak are also familiar with the terms 'close family' and 'distant family'. Close family such as family in law and all close family from the husband or wife either up or down. While distant relatives are blood relations from fourth cousins to seventh cousins. There is mutual assistance among close relatives for example at certain moments, such as tahlilan (nujuh hari, and so on).

In the context of religion, Islamic religious runs very well. Basic Islamic teachings have been given from an early age through teaching Al Qur'an and praying which are held in some mosques. Assemblies of taklim (Islamic teaching) activities are also effective in several places every week. However, this does not mean that the Malay-Muslim community in Pontianak abandons their fanatical nature, especially local traditions and wisdom. The fanatical nature of tradition is still visible, such as the practice of beliefs related to animism and dynamism that are still maintained, including serapah (curse) and pantang larang (abstinence) (Kurniawan, 2016, 2018a, 2018b).

As a tendency of habitus, fanaticism, namely authenticity fanaticism, tradition, and/or originality which is the character tendency of most of the urban MalayMuslim communities in Pontianak, is a consequence of a set of objective conditions from the material world that tend to have a structuring effect on practices in the social education environment, especially in the family and society. These practices continually instill several principles that manage the emergence of practice (what people do and think about what they do) into individual. The practices tend to reproduce various habits (regularity) in the original objective conditions while adapting to the habitus-governed perception of the ever-changing external environment. So in this context, it can be understood the reason why even though urban Malay-Muslims in Pontianak are in the situation and condition of the urban area typology and have tasted what is called modernization in the millennial era, in reality, the fanatic nature of authenticity fanaticism, tradition, and/or indigenity is still attached as characters of most of them.

\section{Urban Malay-Muslim Families in Pontianak and Character Education Based on Malay Culture for Elementary School-Aged Children}

The character mentioned here is closely related to a person's personality. As the origin of this word, which is from the Greek, namely charassein and means to 
engrave (paint, sculpt or inscribe) (Echols\&Shadily., 2014, p. 214; Ryan \& Bohlin, 1999, p. 5). in Islam, a character can be equated with morality. (Wibowo, 2012, p. 26-27) According to the language, akhlaq comes from Arabic; its singular form is khuluqun, which means 'character, temperament, or behavior'. This sentence contains aspects of conformity with the word khalqun which means 'event', and is closely related to Khaliq which means 'creator', and makhluq which means 'created' (Munawwir, 2002, p. 362).

In the Kamus Besar Bahasa Indonesia (Indonesia Dictionary), the word 'character' refers to the behavior, psychological traits, or morals that distinguish one person from another (Editor Team of Indonesian Dictionary Language Center, 2013, p. 623). That's why a person whose behavior is dishonest, cruel, or greedy is related with a bad character, and on the other hand, someone who is honest and helpful is related with a commendable character. Of course, the merits of this character are related with suitability or propriety (Haidt, 2013, p. 208-209). A person can be called a person of character when his behavior is consistent with the agreed moral rules (Zubaedi, 2011, p. 72-73).

The development of this character cannot be separated from the socio-cultural context that surrounds a person's daily life. Therefore, character education always refers to a system in which a person is educated to be a good person, including aspects of knowledge, awareness or initiative, and behavior (Kurniawan, 2013, p. 18). Character education, which is given intentionally to build a good personality, should be able to describe the integration of family, school, and community (Saptono, 2011, p. 23), which if it is referred to Parsons, is something important (Parsons, 1987, p. 23-27). So, all of these educational environments should be mutually supportive of one another. The character of children who are formed at school gets stronger when they get conditioning support from the family, and so does the community (Kurniawan, 2013, p. 221).

Character education given to children in the family, as mentioned earlier, is a mandate from Law Number 20 of 2003 concerning the National Education System. In this law, especially in article 3 , it is stated that national education aims to develop and shape the character and civilization of a dignified nation in the context of the nation's intelligence, encourage the development of children's potential, and build individuals who believe and fear God Almighty, have 
character, are healthy, knowledgeable, capable, creative, independent, and become a democratic and responsible citizen. Based on this law, it is also stated that the family is part of the social environment of informal education, also referred to as an out-of-school education unit. The importance of the family in shaping the character is recognized by our education system (Editor of Sinar Grafika, 2003).

This is quite logical, considering that the family is the first and most primary educational social environment for children so that it becomes the first and primary for their character. Through parents and other adults in the family, an elementary school-aged child can get direction and moral example, or vice versa. Moreover, it is understandable how these children spend more time in their social interactions within the family. So it can be assumed, the existence of a social environment of family education provides capital for the education given or experienced by a child in the social environment of education afterward, either at school or in the community. The family in this context lays the foundation for character education.

In urban Malay-Muslim families in Pontianak generally realize the importance of character education given to children, since their children are in elementary school. They realize that their children are God's mandate to them as parents. They realize, when their child is born, in their nature they are clean like a white paper on which they receive all the scribbles that are given; gravitate towards whatever is skewed for them. Therefore, they are very aware of the importance of habituation that encourages these elementary school-aged children to tend to good traits and behavior. They think that when their children get an example, are taught and accustomed to good character and behavior, they must be good, and vice versa. This tendency strengthens the existence of the family as one of the important educational social environments and affects the character or personality of a child if referring to the view of HM Arifin (Arifin, 1976, p. 83).

Theoretically, as expressed by most experts, the family becomes an educational social environment where for the first time a child gets educational experience, is taught, and receives examples of character. In the social environment of family education, it is also a realm that for the first time a child gets the experience of communicating and interacting with individuals other 
than himself. So that in this educational social environment, children are formed for the first time, both their attitude and personality, which will be attached as the character (Wahyu, 2012, p. 245).

Thus it becomes important for a family to create situations and conditions that support character education (Kurniawan, 2013, p. 64). In Pontianak, parents from urban Malay-Muslim families recognize the importance of religious teaching. According to them, religious teaching is important, so that their children are close to religion. The role of the family in Pontianak as a social educational environment for children is indeed quite large, where the family as a social educational environment plays a primary role in building character, from infancy, childhood, and then elementary school-aged. In this educational social environment, parents, relatives, family, and so on who have considered adults are important actors in character education. It is called important because they are responsible and determine the success or failure of the character education provided especially parents who are indeed required to be role models for their children of elementary school-aged children in the context of character building. This tendency is quite logical if we refer to the view of M. Murtako (Murtako, 2015, p. 149).

Kamrani Buseri explained how the role of the social environment in family education should build children's character, which according to him is reflected in: first, the status, functions, and responsibilities of the family; second, family and socialization process; third, family and affection growth; and fourth, family and status attainment. According to him, strategies that can be used include exemplary, habituation, and teaching. Contact that occurs in the relationship between family members is a process of character education for children. Apart from that, according to Buseri, it is also necessary to pay attention to the process between relationships so that relationships always occur in a positive context; not in a negative context. It is important to note that the social environment of family education as the foundation and basis of character education will further develop positively when it gets support from other educational social environments, namely the social environment of education in schools/colleges and the community. According to Buseri, character education for the nation's children needs to be carried out seriously, well-planned, and full of purpose and synergistically, both in structural and cultural terms (Buseri, 2012, p. 11). 
As an educational social environment that is important for character education, a family represents at least two functions: First, as a social institution; and second, as a religious institution. As a social institution, the family must develop children's nature and potential talents so that the education given to children should not be education that forces children's mindset to develop according to their parents's mindset. Children must develop themselves naturally and according to their potential talents, and parents play a limited role in directing and ensuring that these natures and potentials develop in a positive direction. The family is a society and the state miniature. Therefore, social responsibility that has been formed and grown naturally or manipulately in the family will become awareness for the realization of a good society, which in turn is good for the sustainability of the country. Second, as a religious institution. In this context, it becomes important the position and role of the family, especially in instilling the religious character of children which is an important part of the character education given to them (Kurniawan, 2013, p. 63-65).

There is nothing written about the structure of life and rules for behavior in the life of the Muslim-Malay urban community in Pontianak, and generally, family is the smallest social unit. However, these rules can be understood and manifested in their daily lives, since they are in the family and become each member's habituation. Without structuring and norms in behavior, this will have an impact on children's bad behavior. This seems to be well realized by some parents from families in this community. Norms governing behavior are also made appropriately so that they should not be a burden in carrying them out. With these behavioral norms, which although more 'unwritten', every family member still needs to enforce them consistently and responsibly. However, these elementary school-aged children are individuals who are growing and developing and are in the process of finding their identity. So that in this realm, parental wisdom is very much needed in controlling and directing these children, in line with their stages and development capacities.

The firm attitude of parents in providing education is also needed to enforce positive rules of behavior in building the character of their elementary-aged children. However, from our observations, a small proportion of parents have not been able to do so. For example, the application of study hours or curfews 
(i.e. time limits for going out at night). However, due to excessive affection for children, this often makes parents feel uncomfortable not to indulge their children with unnecessary needs.

Some parents in urban Malay-Muslim families in Pontianak are sometimes too tolerant. This attitude pretends to make their elementary school-aged children grow and develop with a spoiled and selfish nature. If it is continuously used and becomes a habitus, then their children may eventually grow up to become someone with a hard-hearted character, acting as they please regardless of the structuration and behavioral norms that surround them. Habituation of character in the social environment of family education should not be understood as a natural job, but as a continuous and gradual process, in line with the capacity of children's growth and development. This character habituation is an important part of character education because in this section there is the habituation of values and moral behavior by children.

This habituation by parents can be done by them by making a division of tasks and exercises for children in being responsible, such as the task of cleaning the house, helping their parents's business, and many others. Theoretically, the involvement of elementary school-aged children in doing houseworks is not only beneficial for them but also for parents. Then they will carry out these activities carefully and seriously because they are example for other children. In turn, this will also affect the quality and benefits of communication and interaction between them and their children (Adiwikarta, 1998, p. 79).

Involving children in houseworks is to get them used to be diligent and responsible for the tasks assigned to them. Because through the division of tasks, a child gets certain tasks, receives authority, and is responsible for completing the tasks charged to them. Based on the results of our research, the involvement of children in the division of tasks in doing housewroks is only to train them so that they do not grow and develop as lazy children, even though their parents can provide an assistant to complete the houseworks. Even if there is an assistant, at least there are jobs that the children can do on themselves, such as washing their underwear. The impression is simple, but in this context, the practice is to be independent and responsible. In line with this, Kamrani Buseri argued that indeed, parents must help children in achieving their needs, but it should not be 
excessive and eliminate the opportunity for children to learn to be independent and responsible (Buseri, 2012, p. 10).

Of course, the division of tasks or houseworks that are divided and distributed to children is still within reasonableness and propriety and does not interfere with their study hours. This division of works or tasks is not more than job training, so that they become diligent children; realize the importance of houseworks, practice independence, and responsibility. As we observed in an urban Malay-Muslim family in Pontianak, the division of tasks or houseworks is adjusted to the the children's gender, whether it is a boy or a girl. Nevertheless, there are occasional exchanges of types of work or task, to relieve boredom or provide new learning experiences for children, which are tailored to their abilities and age.

The harmony in attitude and behavior in educating is something that is considered important for parents from urban Malay-Muslim families in Pontianak. According to them, this is necessary to make their children not to see inconsistencies occur. For example, at one time talking about the importance of morals and manners, but at other times not showing behavior that reflects a moral, polite and courteous personality. This parent from an urban MalayMuslim family in Pontianak realizes the importance of this consistency because they fear that there will be a conflict in the children's personality, which is counterproductive to the character education goal.

This tendency is quite logical, because in this context too, parents can be role models for their children. If parents want their elementary school-aged children to develop into honest individuals, then they should set a real example. Likewise, if parents want their children to develop into individuals who are religious, diligent, independent, responsible, and so on, they should be role models.

Generally, parents from urban Malay-Muslim families in Pontianak agree that parent-child communication should be based on love, not violence and rejection. Affection here can mean an emotional feeling that is closely tied between parents and children. The form of expression can be in various forms and ways, such as being in a warm situation when communicating, responding immediately to children's needs, comforting when are sad, and so on. In this 
context, intensity and quality are important. When parents manage to express their affection naturally and the message reaches their children, this becomes a positive thing because it provides good social and communication skills, cares for each other and is good at overcoming various social problems they encounter in the future day wisely (Kurniawan, 2013, p. 74).

The opposite of this attitude is violence, and discrimination against children. Forms of violence generally are physical punishments that do not reflect affection. Whatever the reason, intentional or not, violent treatments on children tend to be accepted by them as a form of rejection and feelings of displeasure for their parents. This is counterproductive to the growth and development of their character. One of the effects, children are less able to control their emotions, become less enthusiastic in exploring themselves. In other cases, such treatment may leave an imprint on the heart into feelings of displeasure, hatred, and even resentment towards parents (Kurniawan, 2013, p. 73).

This does not mean that the Malay culture-based character education model practiced in urban Malay-Muslim families in Pontianak does not use corporal punishment at all. The use of corporal punishment in their midst is considered correct when the level of punishment has previously been measured according to appropriateness or propriety. Corporal punishment can be given if the motive is to educate, and even then after other methods are considered less successful. In Pontianak, before parents give corporal punishment, they should: first, give an argument to the children about the reasons why they received punishment; second, provide positive punishment alternatives for the development of children's character; third, limit verbal punishment and avoid the use of physical punishment as much as possible; and fourth, be given only when the unwanted behavior occurs, not when the behavior has become chronic.

Apart from that, urban Malay-Muslim families in Pontianak also still recognize pantang larang (abstinence) as part of a distinctive strategic form of the Malay culture-based character education model that they practice. Abstinence is still given as an educational package to their children of primary school-aged. The same trend can also be found in Muslim-Malays in Sambas where some parents in this community also recognize this abstinence as a strategy in building the character of their elementary school-aged children (Kurniawan, 2016, p. 113-124, 
2018a, p. 87-104). This is easy to understand, considering that the Malay-Muslims of Pontianak and Sambas have relatively identical cultures with each other. The same applies to children's education (Suratman \& Arif, 2020, p. 215-230).

Concerning this abstinence, based on the results of the research, it is identified some abstinence that is still practiced in urban Malay-Muslim families in Pontianak. See table 1 below:

Table 1. Abstinence in an Urban Malay-Muslim Family in Pontianak

\begin{tabular}{|c|c|c|c|}
\hline No & Abstinence & Believed Consequences & Rationalization \\
\hline 1 & $\begin{array}{l}\text { Not allowed to sit in front } \\
\text { of the door of the house to } \\
\text { block people in and out }\end{array}$ & Hard to get a mate & Less polite \\
\hline 2 & $\begin{array}{l}\text { Not allowed to sleep under } \\
\text { the window }\end{array}$ & Stepped by a ghost & Less polite \\
\hline 3 & $\begin{array}{l}\text { Not allowed to play "tapuk } \\
\text { pipet" at night, especially } \\
\text { Friday night }\end{array}$ & Hidden by a ghost & $\begin{array}{l}\text { At night, it's time to rest. It's not } \\
\text { time to play. }\end{array}$ \\
\hline 4 & $\begin{array}{l}\text { Not allowed to stay under } \\
\text { the hot rain }\end{array}$ & Severe pain/fever & $\begin{array}{l}\text { Hot rain is medically known as } \\
\text { bad for health. }\end{array}$ \\
\hline 5 & $\begin{array}{l}\text { Not allowed to cut nails at } \\
\text { night }\end{array}$ & Short life & $\begin{array}{l}\text { A night light that is not bright } \\
\text { can cause errors in cutting the } \\
\text { nails which have an impact on } \\
\text { the skin around the nails due to } \\
\text { clipping. }\end{array}$ \\
\hline 6 & $\begin{array}{l}\text { Not allowed whistle in the } \\
\text { middle of the night }\end{array}$ & Visited by a ghost & Less polite \\
\hline 7 & $\begin{array}{l}\text { Not allowed to sit on the } \\
\text { pillow }\end{array}$ & Boil & Less polite \\
\hline 8 & $\begin{array}{l}\text { Not allowed to burn the } \\
\text { shrimp paste in the middle } \\
\text { of the night }\end{array}$ & Inviting ghosts & The smell is annoying. \\
\hline 9 & $\begin{array}{l}\text { Not allowed to play under } \\
\text { the clothesline }\end{array}$ & Short life & $\begin{array}{l}\text { It can make the clothesline fall } \\
\text { to the ground due to being hit } \\
\text { while playing. }\end{array}$ \\
\hline 10 & Not allowed to leave food & $\begin{array}{l}\text { The beloved pet will } \\
\text { die. }\end{array}$ & Wasteful \\
\hline
\end{tabular}


Syamsul Kurniawan and Muhammad Miftah

\begin{tabular}{llll}
\hline \hline 11 & $\begin{array}{l}\text { Not allowed to pee } \\
\text { anywhere }\end{array}$ & $\begin{array}{l}\text { Got skin disease due to } \\
\text { ghost urination }\end{array}$ & $\begin{array}{l}\text { Environmental wisdom } \\
\text { teachings }\end{array}$ \\
\hline 12 & $\begin{array}{l}\text { Do not refuse food served } \\
\text { by the host }\end{array}$ & Unlucky & Appreciating the host \\
\hline
\end{tabular}

Based on the research findings, abstinence is still practiced in urban MalayMuslim families in Pontianak today, it was deliberately made by the ancestors to deal with the environment where they live, and then make that knowledge to be a part of the culture or local wisdom, and introduce and pass it on from generation to generation to the next children. This abstinence itself, implies a very deep message, such as the importance of establishing good relations with others and nature, as well as developing ethics or manners in daily life. Likewise, it is implied from abstinence which is generally applied in urban Malay-Muslim families in Pontianak.

Apart from that, character education in this urban Malay-Muslim family in Pontianak faced several challenges that are a consequence of today's social changes. This era is indicated by various sophistications of media and digital technology. Moreover, the children live in urban areas such as Pontianak. The opportunity for them to interact with the sophistication of media and digital technology is very large. Furthermore, they were born as digital natives, not as digital immigrants like their parents (Prensky, 2001, p. 1-6).

The progress of the times indicated by the sophistication of media and digital technology, besides having benefits, also has disadvantages for these children. One of them is character deterioration (Prihatmojo \& Badawi, 2020, p. 143). It is called so, because the familiarity of elementary-aged children today with communication, media, and digital technology can have a positive or negative impact, it all depends on their ability to filter the information they read and download. It is similar to the use of social media, such as Facebook, Instagram, WhatsApp, youtube, and others. Through this social media, they can connect with anyone from any background.

In urban Pontianak, parents from Malay-Muslim families admit to a dilemma. On the one hand, it is impossible in this day and age to keep their children away, for example from smartphones. But on the other hand, they are also 
aware of the bad effects when their children are too familiar with smartphones. This consequence, as we indicated above, becomes a challenge for them, because more or less will affect the results that may be achieved from the Malay culturebased character education model that is practiced.

\section{CONCLUSION}

Based on the research findings, urban Malay-Muslim families in Pontianak practice a model of character education based on Malay culture for their elementary-aged children. The character education provided by most parents from urban Malay Muslim families in Pontianak is in the form of the application of virtue and exemplary values which are sourced from their Malay culture. The model is through intervention and habituation of values that are practiced in everyday life.

But this is certainly not always well. Many challenges must also be faced as a consequence of today's social changes. Currently, for example, elementary school-aged children have interacted with the sophistication of digital media and technology, which allows them to download information about anything and from anywhere. Likewise, the familiarity of these elementary-aged children with social media, such as Facebook, Instagram, WhatsApp, YouTube, and so on. There is no guarantee if this tendency does not have a bad influence on the development of their character. So it is important for parents in this community to show their commitment in assisting their children to ward off bad influences caused by such tendencies. 


\section{REFERENCES}

Adiwikarta, S. (1998). Sosiologi Pendidikan: Isu dan Hipotesis tentang Hubungan Pendidikan dan Masyarakat. Direktorat Jenderal Pendidikan Tinggi Proyek Pengembangan Lembaga Pendidikan Tenaga Kependidikan.

Al-Qur'an dan Terjemahan (Departemen Agama Republik Indonesia, Penerj.). (1993). Gema Risalah Press.

Arifin, M. (1976). Hubungan Timbal Balik Pendidikan Agama: Di Lingkungan Sekolah dan Keluarga. Bulan Bintang.

Azzet, A. M. (2016). Urgensi Pendidikan Karakter di Indonesia: Revitalisasi Pendidikan Karakter terhadap Keberhasilan Belajar dan Kemajuan Bangsa. Arruzz Media.

Bappeda Kota Pontianak. (2018, September 20). Kondisi Geografis dan Demografi Pemerintah Kota Pontianak. Bappeda Kota Pontianak. http:/ / bappeda. pontianakkota.go.id/berita/kondisi-geografis-dan-demografipemerintah-kota-pontianak-

Buseri, K. (2012, Januari 28). Signifikansi Peran Keluarga Bagi Pendidikan Karakter: Keharusan Struktural dan Kultural [Makalah]. Stadium General Pascasarjana STAIN Pontianak, STAIN Pontianak.

Creswell, J. W. (2009). Research design: Qualitative, quantitative, and mixed methods approaches (3th ed). SAGE Publications.

Echols, J. M \& Shadily, H., (2014). Kamus Inggris-Indonesia. Jakarta: Gramedia Pustaka Utama.

Haidt, J. (2013). The Righteous Mind: Why Good People are Divided by Politics and Religion. Vintage Books.

Itsnaini, A. N., Munawaroh, D. A., Widyastuti, S. W., Sholihah, N., \& Hanik, E. U. (2021). IMPLEMENTASI PEMBANGUNAN KARAKTER DAN KREATIVITAS PEMBELAJARAN SISWA MELALUI PROGRAM UTAMA PADASEKOLAHINDONESIA KUALA LUMPUR(SIKL). JKPD (Jurnal Kajian Pendidikan Dasar), 6(1), 14-23. 
Jpnn.com. (2019, Desember). Sepanjang 2019, 153 Anak jadi Korban Fisik dan Bullying. JPNN.COM. https://www.jpnn.com/news/sepanjang-2019153-anak-jadi-korban-fisik-dan-bullying.

Kompas.com. (2020, Maret 12). Siswi Kelas II SD Diduga Alami Pelecehan Seksual oleh 4 Kakak Kelas, Diselesaikan Secara Adat. Kompas.com. https:// regional.kompas.com/read/2020/03/12/12120011/siswi-kelas-ii-sddiduga-alami-pelecehan-seksual-oleh-4-kakak-kelas?page=all .

Kurniawan, S. (2013). Pendidikan Karakter: Konsepsi \& Implementasi Secara Terpadu di Lingkungan Keluarga, Sekolah, Perguruan Tinggi, dan Masyarakat. Ar-Ruzz Media.

Kurniawan, S. (2016). Pantang Larang in The Sepinggan Village Muslim Community from The Perspective of Character Education. Ta'dib, 21(2), 113-124. https://doi.org/10.19109/tjie.v21i2.771.

Kurniawan, S. (2018a). Pantang Larang and the Environmental Wisdom of Sambasness Malay in the Sepinggan Village. Kalam, 12(1), 87-104. https://doi.org/10.24042/klm.v12i1.1882.

Kurniawan, S. (2018b). Globalisasi, Pendidikan Karakter, dan Kearifan Lokal yang Hybrid Islam pada Orang Melayu Kalimantan Barat. Jurnal Penelitian, 12(2), 317-354. https:// doi.org/10.21043/jp.v12i2.4899.

Miles, M. B., Huberman, A. M., \& Saldaña, J. (2014). Qualitative Data Analysis: A Methods Sourcebook (Third edition). SAGE Publications, Inc.

Miftah, Muhammad. (2017) Model Integrasi Sains dan Tehnologi dalam Pendidikan Nasional. Jurnal Penelitian, 14 (2), 233-246. DOI: https:// doi.org/10.28918/jupe.v14i2.1214.

Munawwir, A. W. (2002). Al-Munawwir: Kamus Arab-Indonesia. Pustaka Progresif.

Ode, M. L. (1997). Tiga Muka Etnis Cina-Indonesia; Fenomena di Kalimantan Barat. Bayu Indra Grafika.

Okezone. (2018, Maret 31). KPAI: Darurat Pornografi pada Anak SD, Orangtua Harus Tingkatkan Pengawasan. okenews. https://nasional.okezone. com/read/2018/03/31/337/1880311/kpai-darurat-pornografi-padaanak-sd-orangtua-harus-tingkatkan-pengawasan. 
Parsons, T. (1987). On Institutions and Social Evolution: Selected Writings (Leon H. Mayhew, Ed.; 3 ed.). University of Chicago Press.

Rahayuningtyas, D. R., Rizqi, P. A., Putri, R. F. M., Sawwama, A., \& Ahsani, E. L. F. (2021). Peran Guru Dalam Mempertahankan Cultural Heritage Indonesia Dalam Membentuk Karakter Siswa di Sekolah Indonesia Kuala Lumpur. PENSA : Jurnal Pendidikan Dan Ilmu Sosial, 3(April), 2737. https://doi.org/https://doi.org/10.36088/pensa.v3i1.1126.

Redaksi Sinar Grafika (Ed.). (2003). Undang-Undang Nomor 20 tahun 2003 tentang Sistem Pendidikan Nasional. Sinar Grafika.

Ryan, K., \& Bohlin, K. E. (1999). Building Character: How Our Schools Can Teach Respect and Responsibility. Bantam Books.

Saptono. (2011). Dimensi-dimensi Pendidikan Karakter: Wawasan, Strategi, dan Langkah Praktis. Esensi.

Soekamto, S. (2009). Sosiologi: Suatu Pengantar. Rajawali Press.

Tim Redaksi Kamus Besar Bahasa Indonesia Pusat Bahasa. (2013). Kamus Besar Bahasa Indonesia. Gramedia Pustaka Utama.

Wibowo, A. (2012). Pendidikan karakter: Strategi membangun karakter bangsa berperadaban (Cet. 1). Pustaka Pelajar.

Yaumi, M. (2014). Pendidikan Karakter: Landasan, Pilar, dan Implementasi. Kencana.

Zubaedi. (2011). Desain Pendidikan Karakter: Konsepsi dan Aplikasinya dalam Lembaga Pendidikan. Kencana. 